\title{
PENERAPAN PEMBELAJARAN KOOPERATIF TIPE STAD DAN PENGARUHNYA TERHADAP HASIL BELAJAR KOGNITIF DAN KECAKAPAN SOSIAL DITINJAU DARI SIKAP ILMIAH PESERTA DIDIK
}

\author{
Hadi Kusuma Ningrat ${ }^{1}$ \\ 1 Universitas Islam Negeri Mataram, Nusa Tenggara Barat, Indonesia \\ 1hadiknt@uinmataram.ac.id
}

\begin{abstract}
Abstrak
Penelitian ini bertujuan untuk mengetahui pengaruh model pembelajaran kooperatif tipe STAD yang diintegrasikan melalui sikap ilmiah terhadap hasil belajar kognitif dan kecakapan sosial siswa. Metode penelitian yang digunakan adalah metode eksperimen semu dengan desain penelitian faktorial $2 \times 2$. Populasi penelitian adalah semua siswa SMPN 1 Sakra Lombok Timur NTB. Sampel penelitian berjumlah 64 peserta didik yang terbagi menjadi 2 kelas. Instrumen penelitian berupa angket kecakapan sosial, angket sikap ilmiah, dan tes hasil belajar kognitif yang diberikan pada awal dan akhir penelitian. Data hasil penelitian dianalisis dengan Anakova dua jalur. Hasil penelitian menunjukkan bahwa: 1) model pembelajaran kooperatif tipe STAD berpengaruh terhadap hasil belajar kognitif peserta didik, (2) sikap ilmiah peserta didik tidak berpengaruh terhadap hasil belajar kognitif peserta didik, (3) interaksi antara model pembelajaran dan sikap ilmiah peserta didik tidak berpengaruh terhadap hasil belajar kognitif peserta didik, (4) model pembelajaran kooperatif tipe STAD berpengaruh terhadap kecakapan sosial peserta didik, (5) sikap ilmiah peserta didik tidak berpengaruh terhadap kecakapan sosial peserta didik., dan (6) interaksi antara model pembelajaran dan sikap ilmiah peserta didik berpengaruh terhadap kecakapan sosial peserta didik.
\end{abstract}

Kata kunci: STAD; Sikap Ilmiah; Kecakapan Sosial; Hasil Belajar Kognitif;

\begin{abstract}
This study aims to determine the effect of STAD type cooperative learning model that is integrated through a scientific attitude toward the students' cognitive learning outcomes and social skills. The research method used is a quasi-experimental method with $2 \times 2$ factorial research design. The population of the study were students SMPN 1 Sakra Lombok Timur NTB. The sample is 64 students, divided into 2 classes. The research instrument is in the form of a questionnaire of social skills, a questionnaire of scientific attitudes, and tests of cognitive learning outcomes given at the beginning and end of the study. The data of the research were analyzed with Anakova two lanes. The results showed that (1) the students who used STAD type cooperative learning model differed significantly on
\end{abstract}


the cognitive learning outcomes compared to the students who studied with direct learning, (2) the students who had high scientific attitude were not significantly different in the cognitive learning outcomes compared to the students with (3) there is no interaction effect between the learning model and the scientific attitude toward the students' cognitive learning outcomes, (4) the students who learn to use STAD type cooperative learning model differ significantly on social skills aspect than the students who learn by direct learning, 5) students who have a high scientific attitude are not significantly different in the aspects of social skills than students with low scientific attitude, (6) there is interaction influence between the learning model with the scientific attitude toward students' social skills.

Keywords: STAD; Scientific Attitudes; Social Skills; Cognitive Learning Outcomes;

\section{PENDAHULUAN}

Pelajaran ilmu agama pada jenjang sekolah mendasari perkembangan kecintaan peserta didik terhadap Sang Pencipta dan ciptaan-Nya. Sebagai ilmu yang mempelajari kebaikan hidup dunia maupun akhirat, ilmu agama memberikan pelajaran yang baik kepada manusia untuk hidup selaras berdasarkan Firman Allah SWT dan Sabda Rasulullah SAW.

Pada tingkat sekolah, mata pelajaran Pendidikan Agama Islam (PAI) dipandang penting untuk diajarkan sebagai mata pelajaran tersendiri dengan beberapa pertimbangan. Pertama, selain memberikan bekal ilmu kepada peserta didik, penanaman ilmu agama sejak dini, akan memberi arti yang luar biasa terhadap keluhuran akhlak dan budi pekerti yang baik. Kedua, mata pelajaran agama perlu diajarkan untuk tujuan yang lebih khusus yaitu membekali peserta didik dengan pengetahuan dan pemahaman serta sejumlah kemampuan yang dipersyaratkan untuk memasuki jenjang yang lebih tinggi.

Dalam pembelajaran PAI selama ini timbul masalah-masalah yang perlu dicari solusinya. Umumnya masalah yang timbul adalah kurang memahami materi yang disampaikan guru. Hal ini dipengaruhi oleh pembelajaran yang 
Ningrat, H. (2018). PENERAPAN PEMBELAJARAN KOOPERATIF TIPE STAD DAN PENGARUHNYA TERHADAP HASIL BELAJAR KOGNITIF DAN KECAKAPAN SOSIAL DITINJAU DARI SIKAP ILMIAH PESERTA DIDIK. Jurnal Tatsqif, 16(2). Retrieved from http://journal.uinmataram.ac.id/index.php/tatsqif/article/view/307

masih berpusat pada guru dan kurangnya variasi dalam pembelajaran, sehingga menjadikan peserta didik kurang aktif dalam mendapatkan pengetahuan. Dilihat dari hal tersebut, maka perlu diusahakan agar pelajaran menjadi lebih menarik, dan tidak membosankan. Guru dituntut pandai dalam menerapkan suatu strategi atau model pembelajaran yang tepat sesuai dengan karakteristik suatu pokok bahasan, sehingga tujuan pembelajaran dapat tercapai dengan baik.

Selain masalah di atas, keterampilan sosial peserta didik masih belum terbina dengan baik, hal ini dibuktikan dengan: a) saling menghargai antar peserta didik masih rendah, b) komunikasi antar peserta didik belum menerapkan nilai yang islami, c) kerjasama yang konstruktif dalam pembelajaran masih belum terbina dengan baik, d) dalam proses pembelajaran peserta didik cendrung bersifat individualis, dan e) terkadang sering keluar kata-kata kotor pada saat peserta didik berbincang dengan temannya.

Salah satu upaya untuk memperbaiki dan meningkatkan hasil belajar kognitif dan sikap sosial peserta didik adalah dengan melakukan perbaikan dan inovasi dalam proses pembelajaran. Upaya perbaikan dapat dilakukan dengan menerapkan model pembelajaran yang tepat agar proses pembelajaran lebih terarah dan terukur. Alternatif model pembelajaran yang cocok dengan mata pelajaran PAI adalah model pembelajaran kooperatif, yang sesuai dengan pendekatan konstruktivisme. Dalam konstruktivisme, peserta didik secara aktif membangun pengetahuan mereka sendiri. Peran guru adalah membantu peserta didik menemukan fakta, konsep atau prinsip bagi diri mereka sendiri, bukan memberikan ceramah atau mengendalikan seluruh kegiatan kelas. Peserta didik akan lebih mudah menemukan dan memahami konsep-konsep yang sulit apabila mereka dapat saling mendiskusikan masalah-masalah itu dengan temannya (Nur dan Wikandari, 2000).

Menurut pandangan teori motivasi, struktur tujuan kooperatif adalah menciptakan suatu situasi sehingga keberhasilan salah satu anggota kelas 
Ningrat, H. (2018). PENERAPAN PEMBELAJARAN KOOPERATIF TIPE STAD DAN PENGARUHNYA TERHADAP HASIL BELAJAR KOGNITIF DAN KECAKAPAN SOSIAL DITINJAU DARI SIKAP ILMIAH PESERTA DIDIK. Jurnal Tatsqif, 16(2). Retrieved from http://journal.uinmataram.ac.id/index.php/tatsqif/article/view/307

diakibatkan keberhasilan kelas itu sendiri. Oleh karena itu, untuk mencapai tujuan dari salah satu anggota, maka salah seorang anggota tersebut harus membantu teman kelasnya dengan melakukan apa saja yang dapat membantu kelas itu berhasil (Nur dan Wikandari, 2000). Pembelajaran kooperatif adalah strategi pembelajaran dimana peserta didik belajar bersama dalam kelompokkelompok kecil dan saling membantu satu sama lain. Dalam menyelesaikan tugasnya, setiap anggota kelompok saling bekerja sama dan membantu untuk memahami suatu bahan pelajaran. Dalam hal ini belajar dianggap belum selesai apabila seorang anggota dari kelompok belajar itu belum menguasai bahan pelajaran.

Pembelajaran kooperatif memiliki beragam tipe, di antaranya student teams achievement division (STAD), tim ahli (Jigsaw), Number Head Together (NHT), Think Pare Share (TPS) dan model pembelajaran kooperatif lainnya. Pembelajaran kooperatif tipe STAD merupakan pembelajaran kooperatif paling sederhana. Pada model pembelajaran ini peserta didik dibagi dalam kelompok-kelompok kecil dalam menerima materi dan menyelesaikan tugastugas pembelajarannya (Ibrahim dkk, 2000).

Model pembelajaran kooperatif STAD cukup sederhana tetapi berpotensi dalam mendukung berlangsungnya belajar aktif, inovatif, kreatif, efektif dan menyenangkan (PAIKEM). Adanya pemberian penghargaan kepada kelompok pada STAD diasumsikan dapat menumbuhkan suasana menyenangkan bagi peserta didik. Pembelajaran kooperatif dikembangkan untuk mencapai kompetensi akademik, pembelajaran ini juga efektif untuk mengembangkan kompetensi sosial peserta didik, karena dapat menciptakan interaksi yang lebih luas, yaitu interaksi dan komunikasi yang dilakukan antara guru dengan peserta didik, peserta didik dengan peserta didik, dan peserta didik dengan guru (multy way traffic communication). Selain itu pembelajaran kooperatif mengajarkan kepada peserta didik keterampilan kerja sama dan kolaborasi (Rusman, 2011). Pembelajaran kooperatif dikembangkan untuk mencapai setidak-tidaknya tiga tujuan pembelajaran 
Ningrat, H. (2018). PENERAPAN PEMBELAJARAN KOOPERATIF TIPE STAD DAN PENGARUHNYA TERHADAP HASIL BELAJAR KOGNITIF DAN KECAKAPAN SOSIAL DITINJAU DARI SIKAP ILMIAH PESERTA DIDIK. Jurnal Tatsqif, 16(2). Retrieved from http://journal.uinmataram.ac.id/index.php/tatsqif/article/view/307

penting yaitu hasil belajar akademik, penerimaan terhadap keragaman dan pengembangan keterampilan sosial (Arends, 2008).

Berdasarkan uraian di atas peneliti terdorong untuk meningkatkan kemampuan peserta didik tidak hanya dalam aspek kognitif, tetapi juga dalam hal menunjang kecakapan sosial menjadi unsur penting tujuan pembelajaran agama. Melalui model pembelajaran kooperatif tipe STAD ditinjau dari sikap ilmiah peserta didik diharapkan dapat meningkatkan kecakapan sosial dan hasil belajar kognitif peserta didik pada pembelajaran agama.

\section{LANDASAN TEORI}

\section{Model Pembelajaran Kooperatif}

Pembelajaran kooperatif merupakan sekelompok strategi mengajar yang memberikan peran terstruktur bagi peserta didik sambil menekankan interaksi antar peserta didik. Dalam kooperatif, dua atau lebih individu saling tergantung satu sama lain untuk mencapai satu penghargaan bersama. Mereka akan berbagi penghargaan tersebut seandainya mereka berhasil sebagai kelompok (Eggen dan Kauchak, 2012). Pembelajaran kooperatif dikembangkan untuk mencapai tiga tujuan pembelajaran penting yaitu hasil belajar akademik, penerimaan terhadap keragaman, dan pengembangan keterampilan sosial. Pembelajaran kooperatif dapat meningkatkan kinerja peserta didik dalam tugas-tugas akademik. Selain itu model ini unggul dalam membantu peserta didik memahami konsep-konsep yang sulit (Ibrahim dkk, 2000).

Pembelajaran kooperatif tidak hanya mencakup beragam tujuan sosial, tetapi juga dimaksudkan untuk meningkatkan kinerja peserta didik dalam tugas-tugas akademik yang penting. Para pendukungnya percaya bahwa struktur reward (penghargaan) peserta didik pada pembelajaran akademik dapat mengubah norma-norma yang terkait dengan prestasi (Arends, 2008). Bentuk pembelajaran kooperatif yang sudah luas dikenal yaitu Student Teams Achievement Divisions (STAD). 
Ningrat, H. (2018). PENERAPAN PEMBELAJARAN KOOPERATIF TIPE STAD DAN PENGARUHNYA TERHADAP HASIL BELAJAR KOGNITIF DAN KECAKAPAN SOSIAL DITINJAU DARI SIKAP ILMIAH PESERTA DIDIK. Jurnal Tatsqif, 16(2). Retrieved from http://journal.uinmataram.ac.id/index.php/tatsqif/article/view/307

STAD dikembangkan oleh Robert Slavin dan teman-temannya di Universitas John Hopkins. STAD merupakan pembelajaran kooperatif yang paling sederhana (Arends, 2008). Strategi kooperatif tipe STAD adalah salah satu strategi kooperatif yang banyak diteliti di berbagai ranah pelajaran. Dalam strategi tipe STAD peserta didik dibagi menjadi kelompok-kelompok. Jumlah anggota dalam satu kelompok 4-5 orang yang harus heterogen, terdiri dari laki-laki dan perempuan, memiliki kemampuan tinggi, sedang dan rendah (Slavin, 2011).

2. Sikap Ilmiah

Sikap ilmiah yaitu sikap ingin tahu tentang benda, fenomena alam, makhluk hidup, serta hubungan sebab akibat yang menimbulkan masalah baru yang dapat dipecahkan melalui prosedur yang benar. Sikap ilmiah merupakan salah satu unsur yang ada di hakikat IPA (Puskur, 2007a).

Indikator sikap ilmiah pada kelas IX pada jenjang sekolah menengah diarahkan untuk mengacu pada project 2061 National Sciences Education Standard (NSES) yang dirokemendasikan oleh Hassard \& Dias (2009) dan dikombinasikan dengan indikator yang dikeluarkan oleh BSNP (2006) dan Arifin (2008) yaitu: sikap curiosity (sifat ingin tahu), honesty (kejujuran), openness (keterbukaan), skepticism (skeptis), objektif, tanggung jawab, disiplin, teliti, sikap berani mempertahankan kebenaran, dan sikap menjangkau ke depan.

\section{Hasil Belajar Kognitif}

Hasil belajar adalah kemampuan-kemampuan yang dimiliki peserta didik setelah ia menerima pengalaman belajarnya. Hasil peristiwa belajar dapat muncul dalam berbagai jenis perubahan atau pembuktian tingkah laku seseorang. Dalam sistem pendidikan nasional rumusan tujuan pendidikan, baik tujuan kurikuler maupun tujuan instruksional, menggunakan klasifikasi hasil belajar dalam taksonomi Bloom yang secara garis besar membaginya menjadi tiga domain sebagai berikut: (a) domain kognitif atau kemampuan berpikir, (b) domain afektif berkenaan dengan sikap, dan (c) domain psikomotorik berkenaan dengan keterampilan. Pada penelitian ini hasil 
Ningrat, H. (2018). PENERAPAN PEMBELAJARAN KOOPERATIF TIPE STAD DAN PENGARUHNYA TERHADAP HASIL BELAJAR KOGNITIF DAN KECAKAPAN SOSIAL DITINJAU DARI SIKAP ILMIAH PESERTA DIDIK. Jurnal Tatsqif, 16(2). Retrieved from http://journal.uinmataram.ac.id/index.php/tatsqif/article/view/307

belajar yang ingin diteliti berdasarkan enam kategori hasil belajar kognitif dari taksonomi Bloom yang sudah direvisi yaitu kemampuan mengingat (C1), memahami (C2), menerapkan (C3), menganalisis (C4), mengevaluasi (C5), dan mengkreasi (C6) (Anderson \& Krathwohl, 2001).

4. Kecakapan Sosial

Menurut konsepnya kecakapan hidup dibagi menjadi dua jenis utama, yaitu: kecakapan hidup generik dan kecakapan hidup spesifik. Kecakapan hidup generik terdiri atas kecakapan personal (personal skill) dan kecakapan sosial (social skill), sementara kecakapan hidup spesifik dibagi lagi menjadi kecakapan akademik dan kecakapan vokasional. Dominasi pendidikan kecakapan hidup pada jenjang SMP lebih ditekankan pada kecakapan hidup umum (generic life skill), sehingga pada penelitian ini, difokuskan untuk meneliti pada aspek kecakapan sosial yang dapat dipilah menjadi dua jenis utama yaitu kecakapan berkomunikasi dan bekerjasama (Puskur, 2007b).

\section{METODE}

\section{Jenis Penelitian}

Penelitian didasarkan pada pendekatan kuantitatif yang menggunakan pengujian data secara empiris. Jenis penelitian ini adalah kuasi eksperimen yaitu untuk melihat pengaruh pembelajaran kooperatif terhadap hasil belajar kognitif dan kecakapan sosial ditinjau dari sikap ilmiah peserta didik.

2. Lokasi dan Waktu Penelitian

Penelitian ini dilaksanakan di Kelas VIIB (Kelas Eksperimen) dan VII E (Kelas Kontrol) di SMPN 1 Sakra Lombok Timur NTB, pada bulan Juli sampai September 2018.

3. Populasi dan Sampel

Populasi dalam penelitian ini adalah seluruh peserta didik kelas VII SMPN 1 Sakra Tahun Pelajaran 2017/2018 sejumlah 360 peserta didik. Pengambilan sampel dilakukan dengan cluster random sampling yaitu pengambilan sampel dengan memperhatikan unsur kelas atau kelompok 
Ningrat, H. (2018). PENERAPAN PEMBELAJARAN KOOPERATIF TIPE STAD DAN PENGARUHNYA TERHADAP HASIL BELAJAR KOGNITIF DAN KECAKAPAN SOSIAL DITINJAU DARI SIKAP ILMIAH PESERTA DIDIK. Jurnal Tatsqif, 16(2). Retrieved from http://journal.uinmataram.ac.id/index.php/tatsqif/article/view/307

yang terdapat dalam populasi. Pengambilan sampel dilakukan dengan memilih dua kelas dari sembilan kelas secara acak setelah melalui uji homogenitas. Masing-masing kelas berisi 32 peserta, sehingga total yang menjadi sampel sekitar 64 peserta didik.

4. Instrumen dan Teknik Pengumpulan Data

Penilaian sikap ilmiah dilakukan melalui angket yang diberikan secara individu mencakup indikator rasa ingin tahu, kejujuran, keterbukaan, skeptis, objektivitas, kedisiplinan, tanggung jawab, keberanian dalam kebenaran, berpikir ke depan dan ketelitian. Penilaian hasil belajar kognitif dilakukan melalui tes hasil belajar berupa 10 soal pilihan ganda dan uraian. Instrumen ini diujicobakan untuk mengetahui validitas, reliabilitas, indeks kesukaran dan daya beda soal. Kecakapan sosial peserta didik diperoleh dari pemberian angket dan observasi.

5. Metode Analisis Data

a. Data sikap ilmiah

Penskoran untuk menganalisis sikap ilmiah peserta didik menggunakan skala Likert 1-5 dengan ketentuan untuk pernyataan kategori positif: jawaban SS = skor $5, \mathrm{~S}=$ skor $4, \mathrm{R}=$ skor 3 , TS $=$ skor 2 dan STS = skor 1. Untuk pernyataan kategori negatif: jawaban SS = skor 1 , $\mathrm{S}=$ skor $2, \mathrm{R}=$ skor $3 \mathrm{TS}=$ skor 4 dan STS = skor 5 . Pengubahan skor ke nilai dilakukan dengan menggunakan skala 0-100. Untuk menentukan kategori sikap ilmiah tinggi dan rendah digunakan $\mathrm{Z}_{\text {score }}$

b. Data hasil belajar kognitif

Data kemampuan hasil belajar kognitif peserta didik menggunakan penskoran tes pilihan ganda. Tiap-tiap skor mentah selanjutnya diubah ke bentuk nilai dengan skala 0-100.

c. Data kecakapan sosial

Penskoran untuk menganalisis data kecakapan hidup peserta didik menggunakan skala Likert 1-5 dengan ketentuan yang sama dengan data sikap ilmiah. 
d. Uji Hipotesis

Uji hipotesis dilakukan dengan Anakova dua jalur (Two Way Anacova). Sebelum dilakukan uji hipotesis, terlebih dahulu dilakukan uji normalitas dan homogenitas data sebagai prasyarat uji statistik parametris. Uji hipotesis dibantu dengan SPSS 18 for windows.

\section{HASIL DAN PEMBAHASAN}

1. Hasil Uji Kelayakan Perangkat Penelitian

Perangkat penelitian yang mencakup Rencana Pelaksanaan Pembelajaran (RPP), Instrumen Penelitian berupa Angket Kecakapan Sosial, Angket Sikap Ilmiah dan Tes Hasil Belajar Kognitif dan Perangkat Pendukung Penelitian seperti Lembar Kerja Peserta didik (LKPD) telah dilakukan validasi sebelum diterapkan dalam penelitian. Hasil uji validasi ahli menunjukkan bahwa perangkat penelitian sangat layak digunakan berdasarkan kategori yang telah ditentukan. Skor rata-rata hasil uji validasi terhadap media dan instrumen penelitian 90,55\%.

2. Hasil Belajar Kognitif Peserta didik

Hasil belajar kognitif siswa yang belajar menggunakan model pembelajaran tipe STAD lebih tinggi dari pada kelas kontrol (postes). Hasil selengkapnya tersaji pada Tabel 1.

Tabel 1. Data Hasil Belajar Kognitif

\begin{tabular}{ccccccc}
\hline Data & $\begin{array}{c}\text { Model } \\
\text { Pembelajaran }\end{array}$ & N & Rerata & S. Dev & $\begin{array}{c}\text { Nilai } \\
\text { Tertinggi }\end{array}$ & $\begin{array}{c}\text { Nilai } \\
\text { Terendah }\end{array}$ \\
\hline \multirow{2}{*}{ Pretes } & STAD & 32 & 56,20 & 5,41 & 65,20 & 46,40 \\
& Langsung & 32 & 56,30 & 5,05 & 65,60 & 46,40 \\
\multirow{2}{*}{ Postes } & STAD & 32 & 81,25 & 5,76 & 93,60 & 66,40 \\
& Langsung & 32 & 69,53 & 4,03 & 80,80 & 60,80 \\
\hline
\end{tabular}

Paningkatan hasil belajar kognitif peserta didik berdasarkan skor Ngain lebih tinggi pada kelas eksperimen dari pada kelas kontrol (Gambar 1). Hal ini berarti implementasi model pembelajaran kooperatif tipe STAD secara deskriptif lebih baik dibandingkan dengan kelas kontrol. 


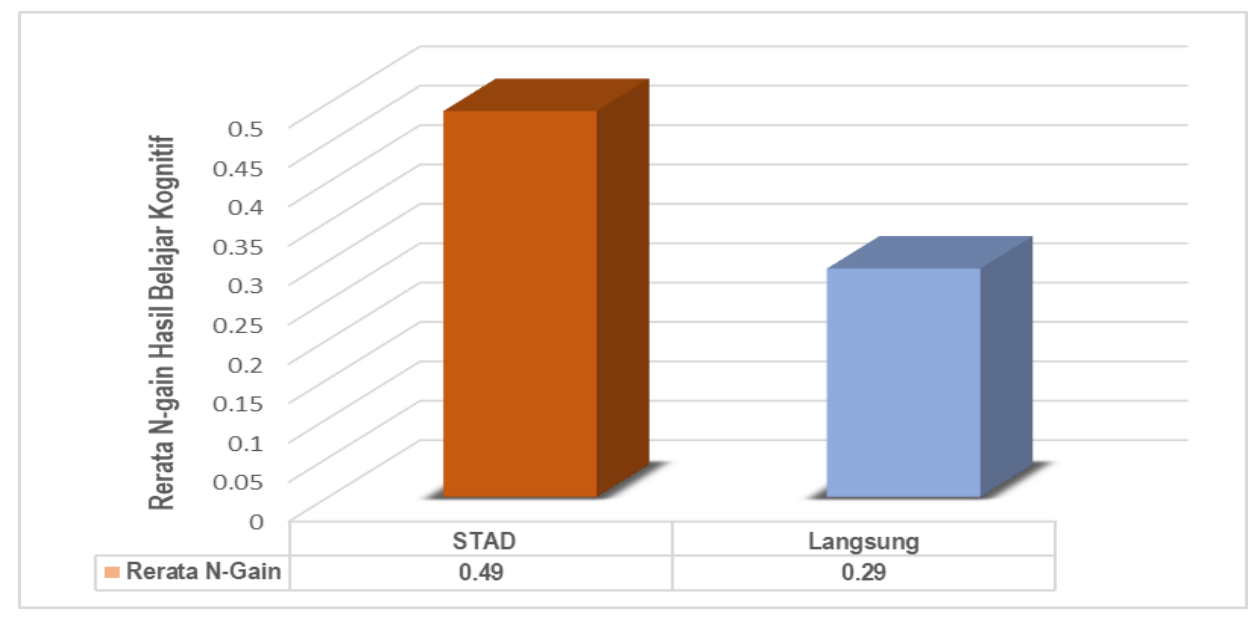

Gambar 1. N-gain Hasil Belajar Kognitif

Uji hipotesis dengan Anakova dua jalur. Sebelum uji hipotesis terlebih dahulu data hasil belajar diuji normalitas dan homogenitas. Hasil uji normalitas data menunjukkan bahwa data hasil belajar kognitif berdistribusi normal dengan ketentuan $\mathrm{P}$ (sig.) $>0$. Hasil uji homogenitas data menunjukkan bahwa data hasil belajar kognitif memiliki nilai $\mathrm{P}$ (sig.) >0 artinya data memiliki varians yang homogen.

a. Pengaruh Model Pembelajaran terhadap Hasil Belajar Kognitif Peserta didik

Hasil penelitian menunjukkan hasil belajar kognitif peserta didik yang belajar dengan menggunakan model pembelajaran kooperatif tipe STAD berbeda signifikan dibandingkan peserta didik yang belajar dengan pembelajaran langsung $(\mathrm{P}<0,05)$. Peserta didik yang belajar dengan model pembelajaran kooperatif tipe STAD memperoleh skor lebih tinggi 16,86\% dibandingkan peserta didik yang belajar dengan pembelajaran langsung. Hal ini menjadi bukti empirik bahwa implementasi pembelajaran kooperatif tipe STAD terhadap hasil belajar kognitif lebih baik dibandingkan dengan pembelajaran langsung.

Pada penelitian ini, pembelajaran kooperatif berkonstribusi dalam meningkatkan hasil belajar peserta didik. Peserta didik akan lebih mudah menemukan dan memahami konsep yang sulit setelah mereka mendiskusikan konsep tersebut dengan teman sebayanya. Strategi 
Ningrat, H. (2018). PENERAPAN PEMBELAJARAN KOOPERATIF TIPE STAD DAN PENGARUHNYA TERHADAP HASIL BELAJAR KOGNITIF DAN KECAKAPAN SOSIAL DITINJAU DARI SIKAP ILMIAH PESERTA DIDIK. Jurnal Tatsqif, 16(2). Retrieved from http://journal.uinmataram.ac.id/index.php/tatsqif/article/view/307

pembelajaran kooperatif melibatkan proses pemikiran setiap anggota kelompok. Belajar secara kooperatif secara tidak langsung memberikan pembelajaran kepada peserta didik cara teman sejawatnya berhasil menyelesaikan masalah dalam satu kelompok melalui pendekatan mereka. Peserta didik yang pintar akan menjadi tutor bagi temannya yang belum bisa. Hal ini berdampak peserta didik yang belum mengerti menjadi paham dan peserta didik yang pintar akan makin terasah kemampuannya karena dengan memberi pelayanan sebagai tutor membutuhkan pemikiran lebih mendalam terkait dengan konsep materi yang ia ajarkan.

Peserta didik yang piawai dalam berkomunikasi baik dalam bahasa lisan maupun tulisan implikasi dari pembelajaran kooperatif akan berdampak pada kemudahan peserta didik tersebut dalam menerima informasi berupa materi pelajaran dari guru maupun temannya. Jika peserta didik tersebut belum mengerti terhadap pelajaran, dia akan menanyakan hal tersebut kepada peserta didik yang lebih paham atau ke gurunya. Peserta didik yang cakap dalam bekerjasama akan memudahkan dia bekerja sebagai anggota dalam kelompok belajar atau sebagai peserta didik dalam kelas untuk memperoleh nilai yang baik pada saat diberikan tugas oleh guru.

b. Pengaruh Sikap Ilmiah terhadap Hasil Belajar Kognitif Peserta didik

Hasil uji hipotesis pengaruh sikap ilmiah peserta didik terhadap hasil belajar kognitif menunjukkan bahwa peserta didik yang memiliki sikap ilmiah tinggi tidak berbeda signifikan dibandingkan sikap ilmiah peserta didik rendah $(\mathrm{P}>0,05)$. Ini menafsirkan bahwa peserta didik yang memiliki sikap ilmiah tinggi maupun rendah memberi hasil yang tidak berbeda secara signifikan dalam meraih hasil belajara kognitif. Namun secara rata-rata rata peserta didik memiliki sikap ilmiah tinggi unggul 2,6\% dari pada peserta didik yang memiliki sikap ilmiah rendah. Hasil ini secara deskriptif sejalan dengan hasil penelitian Arizona dan Harjono (2016) yang membuktikan ada korelasi yang signifikan antara sikap ilmiah dengan hasil belajar kognitif peserta didik. 
Dengan demikian perlu adanya strategi seorang pendidik untuk membina sikap ilmiah peserta didik dengan baik. Peserta didik yang memiliki sikap ilmiah yang baik, membantu mereka untuk meraih nilai yang tinggi. Temuan ini menjadi menarik, karena masalah sikap ilmiah ini menjadi cerminan bagaimana perhatian peserta didik terhadap pelajaran yang akan mereka dalami.

c. Pengaruh Interaksi Model Pembelajaran dan Sikap Ilmiah terhadap Hasil Belajar Kognitif Peserta didik

Hasil analisis data menunjukkan tidak ada pengaruh interaksi antara model pembelajaran dengan sikap ilmiah terhadap hasil belajar kognitif peserta didik $(\mathrm{P}>0,05)$. Hal ini berarti model pembelajaran ketika dipadukan dengan sikap ilmiah peserta didik tidak memberikan hasil yang berbeda secara signifikan dibandingkan dengan tanpa mengintegrasikan keduanya terhadap hasil belajar kognitif peserta didik. Walaupun demikian, analisis deskriptif hasil penelitian menunjukkan implementasi pembelajaran kooperatif tipe STAD dengan sikap ilmiah peserta didik yang tinggi lebih baik dibandingkan dengan pembelajaran tipe STAD dengan sikap ilmiah peserta didik rendah. Begitu pula jika dibandingkan dengan pembelajaran langsung dengan sikap ilmiah peserta didik tinggi maupun rendah.

3. Kecakapan Sosial Peserta didik

Hasil penelitian menunjukkan bahwa kecakapan sosial peserta didik paling tinggi diperoleh pada kelas yang belajar menggunakan model kooperatif tipe STAD baik secara rerata maupun nilai tertinggi dan terendah. Hasil selengkapnya terlihat pada Tabel 2.

Tabel 2. Data Kecakapan Sosial

\begin{tabular}{ccccccc}
\hline Data & $\begin{array}{c}\text { Model } \\
\text { Pembelajaran }\end{array}$ & N & Rerata & S. Dev & $\begin{array}{c}\text { Nilai } \\
\text { Tertinggi }\end{array}$ & $\begin{array}{c}\text { Nilai } \\
\text { Terendah }\end{array}$ \\
\hline \multirow{2}{*}{ Pretes } & STAD & 32 & 71,35 & 5,31 & 80,67 & 59,33 \\
& Langsung & 32 & 71,35 & 5,12 & 80,00 & 61,33 \\
\multirow{2}{*}{ Postes } & STAD & 32 & 86,94 & 3,87 & 91,33 & 74,67 \\
& Langsung & 32 & 75,12 & 4,98 & 86,00 & 64,67 \\
\hline
\end{tabular}


Peningkatan kecakapan sosial berdasarkan skor N-gain pada kelas eksperimen lebih tinggi daripada kelas kontrol (Gambar 2). Hal ini berarti implementasi model pembelajaran kooperatif tipe STAD secara deskriptif lebih baik dibandingkan dengan kelas kontrol.

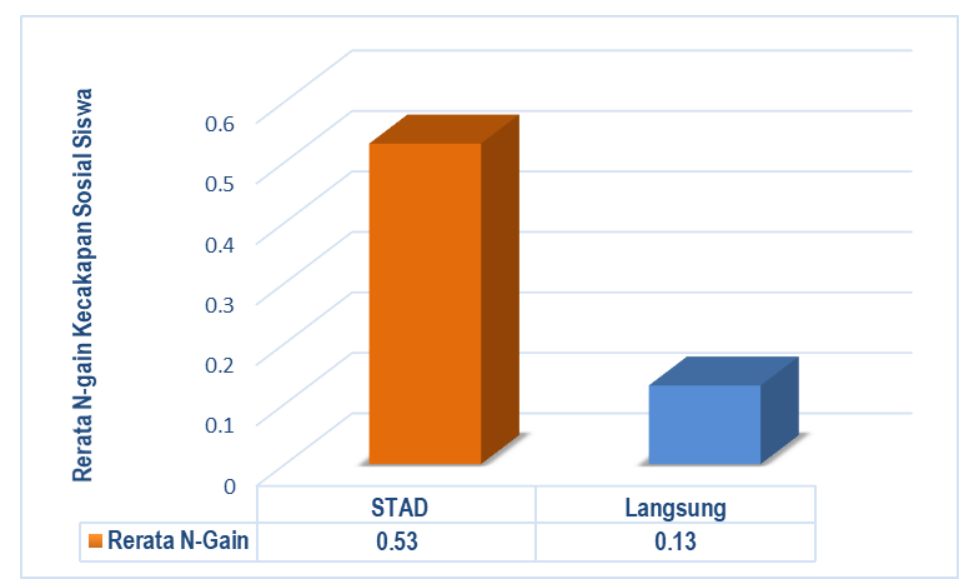

Gambar 2. N-gain Data Kecakapan Sosial

Untuk mengetahui seberapa besar pengaruh model pembelajaran, sikap ilmiah dan pengaruh interaksi antara keduanya dilakukan uji hipotesis menggunaka analisis Anakova dua jalur. Sebelum uji hipotesis terlebih dahulu data kecakapan sosial diuji normalitas dan homogenitas. Hasil uji normalitas data menunjukkan bahwa data kecakapan sosial berdistribusi normal dengan ketentuan $\mathrm{P}$ (sig.) $>0$. Hasil uji homogenitas data menunjukkan bahwa data kecakapan sosial memiliki nilai $\mathrm{P}$ (sig.) $>0$ artinya data memiliki varians yang homogen.

a. Pengaruh Model Pembelajaran terhadap Kecakapan Sosial Peserta didik Hasil uji hipotesis kecakapan sosial menunjukkan bahwa peserta didik yang belajar dengan model pembelajaran kooperatif tipe STAD berbeda signifikan dengan peserta didik yang belajar dengan pembelajaran langsung $(\mathrm{P}<0,05)$. Peserta didik yang belajar dengan STAD memiliki skor kecakapan sosial lebih tinggi 15,73\% dibandingkan peserta didik yang belajar dengan pembelajaran langsung.

Peserta didik yang belajar melalui pembelajaran STAD dibandingkan peserta didik yang belajar dengan pembelajaran langsung 
berbeda signifikan pada ketiga indikator kecakapan sosial yaitu kecakapan berkomunikasi lisan, tulisan dan bekerjasama. Skor peserta didik yang belajar dengan pembelajaran STAD lebih tinggi 12,52\% pada kecakapan berkomunikasi lisan, 20,34\% pada kecakapan berkomunikasi tulisan dan $14,71 \%$ pada kecakapan bekerjasama dibandingkan peserta didik yang belajar melalui pembelajaran langsung. Hal ini membuktikan bahwa pengaruh penerapan pembelajaran STAD terhadap semua indikator kecakapan sosial peserta didik lebih baik dibandingkan dengan pembelajaran langsung.

Strategi kooperatif tipe STAD lebih menekankan pada kecakapan bekerjasama dan berkomunikasi tulisan (berupa kuis pada akhir pembelajaran) serta berkomunikasi lisan saat ada timbal balik dengan gurunya. Sementara pembelajaran langsung lebih kepada berkomunikasi lisan (berupa menjawab pertanyaan langsung/lisan dari gurunya. Pembelajaran STAD melatih peserta didik berkomunikasi dan bekerjasama dibandingkan. Peserta didik yang piawai dalam berkomunikasi secara lisan dan tulisan memudahkan mereka dalam menerima informasi (materi pelajaran) dari guru maupun temannya. Peserta didik yang cakap dalam bekerjasama memudahkan dia bekerja sebagai anggota dalam kelompok belajar atau dalam kelas untuk memperoleh nilai yang baik.

Gagasan utama STAD adalah memacu peserta didik agar saling mendorong dan membantu satu sama lain untuk menguasai keterampilan yang diajarkan guru. Terlihat secara umum dalam penelitian ini, untuk mendapatkan reward (penghargaan) anggota kelompok mendorong temannya untuk melakukan yang terbaik dan saling bekerjasama agar skor kuis yang diberikan di akhir pembelajaran dapat mereka jawab dengan baik. Bagaimanapun, kuis yang diberikan harus mereka kuasai secara individu karena tidak diperkenankan untuk bekerjasama ketika 
Ningrat, H. (2018). PENERAPAN PEMBELAJARAN KOOPERATIF TIPE STAD DAN PENGARUHNYA TERHADAP HASIL BELAJAR KOGNITIF DAN KECAKAPAN SOSIAL DITINJAU DARI SIKAP ILMIAH PESERTA DIDIK. Jurnal Tatsqif, 16(2). Retrieved from http://journal.uinmataram.ac.id/index.php/tatsqif/article/view/307

kuis berlangsung. Hal ini sebagai bentuk tanggung jawab individu terhadap kelompoknya.

Penelitian ini membuktikan bahwa pembelajaran dengan strategi kooperatif sangat membantu peserta didik untuk melatih dan mengembangkan kompetensi kecakapan sosial peserta didik. Pembelajaran kooperatif membantu peserta didik memahami konsepkonsep yang sulit dan menumbuhkan kemampuan peserta didik dalam bekerjasama dan membantu teman. Pembelajaran kooperatif memiliki pengaruh positif dalam memperbaiki hubungan antarkelompok. Penghargaan yang diberikan kepada kelompok yang kinerjanya baik, memicu anggota kelompok memiliki empati membantu teman dalam satu kelompok demi kepentingan bersama.

b. Pengaruh Sikap Ilmiah terhadap Kecakapan Sosial Peserta didik

Hasil analisis data menunjukkan tidak ada perbedaan kecakapan sosial yang signifikan antara peserta didik yang memiliki sikap ilmiah tinggi dengan sikap ilmiah yang rendah $(\mathrm{P}>0,05)$. Walaupun demikian peserta didik yang memiliki sikap ilmiah tinggi memiliki skor kecakapan sosial lebih tinggi 6,14\% dibandingkan peserta didik dengan sikap ilmiah rendah. Hal ini menginterpretasikan bahwa peserta didik dengan sikap ilmiah tinggi lebih baik secara umum untuk menopang aspek kecakapan sosial peserta didik dengan sikap ilmiah rendah, tetapi hal ini tidak berlaku pada semua indikator kecakapan sosial.

Peserta didik yang memiliki sikap ilmiah nampak pada kejujuran, objektivitas, keterbukaan, tanggung jawab dan indikator sikap ilmiah lainnya. Peserta didik yang baik dalam berkomunikasi akan tercermin dari kejujuran lisannya. Laporan atau tugas yang dibuat termuat informasi yang objektif sesuai dengan hasil percobaan atau literatur yang ada. Begitu pula dengan kuis atau ulangan, dijawab sesuai dengan kemampuan tanpa menyontek atau bekerjasama. Peserta didik yang cakap dalam berkomunikasi dan bekerjasama akan senantiasa terbuka dan menghargai pendapat temannya walaupun bertentangan dengan pikirannya. 
Ningrat, H. (2018). PENERAPAN PEMBELAJARAN KOOPERATIF TIPE STAD DAN PENGARUHNYA TERHADAP HASIL BELAJAR KOGNITIF DAN KECAKAPAN SOSIAL DITINJAU DARI SIKAP ILMIAH PESERTA DIDIK. Jurnal Tatsqif, 16(2). Retrieved from http://journal.uinmataram.ac.id/index.php/tatsqif/article/view/307

c. Pengaruh Interaksi Model Pembelajaran Kooperatif Tipe STAD dengan Sikap Ilmiah terhadap Kecakapan Sosial Peserta didik

Hasil uji hipotesis menunjukkan ada pengaruh interaksi model pembelajaran dengan sikap ilmiah peserta didik terhadap kecakapan sosial peserta didik $(\mathrm{P}<0,05)$. Hal ini membuktikan model pembelajaran memberikan hasil yang lebih baik jika diintegrasikan dengan sikap ilmiah peserta didik terhadap kecakapan sosial peserta didik.

Peserta didik yang belajar pada kelas dengan model pembelajaran STAD memiliki kecakapan sosial yang lebih baik. STAD melatih siswa berkomunikasi dan berkerjasama melalui kegiatan diskusi yang dipandu dengan lembar kerjas peserta didik (LKPD). Secara tidak langsung kegiatan ini menjadikan peserta didik berinterakasi dalam kelompoknya seperti bertanya mengenai materi dan beberapa persoalan yang muncul pada LKPD. Peserta didik pada kelas STAD terlihat lebih aktif karena ada tugas yang lebih kompleks yang harus mereka selesaikan. Beda halnya dengan pembelajaran langsung hanya berkutat pada buku pegangan dan penjelasan dari guru dalam menemukan jawaban tanpa bertanya ataupun bekerjasama dengan teman sejawat, sehingga komunikasi dan kerjasama hanya sebatas pada materi yang tertuang pada buku.

Penerapan model pembelajaran kooperatif tipe STAD yang diintegrasikan dengan sikap ilmiah peserta didik menjadi salah satu solusi untuk menopang kecakapan sosial yang sangat penting dimiliki oleh peserta didik. Sebagai makhluk sosial, setiap peserta didik perlu dibekali kecakapan sosial semenjak dini. Dengan bekal kecakapan sosial, seseorang akan dapat menjalani kehidupan dengan baik (Arizona dkk., 2013).

\section{KESIMPULAN}

Berdasarkan hasil penelitian dan uraian pembahasan yang telah disajikan, dapat disimpulkan bahwa:

1. Model pembelajaran kooperatif tipe STAD berpengaruh terhadap hasil belajar kognitif peserta didik. 
2. Sikap ilmiah peserta didik tidak berpengaruh terhadap hasil belajar kognitif peserta didik.

3. Interaksi antara model pembelajaran dan sikap ilmiah peserta didik tidak berpengaruh terhadap hasil belajar kognitif peserta didik.

4. Model pembelajaran kooperatif tipe STAD berpengaruh terhadap kecakapan sosial peserta didik.

5. Sikap ilmiah peserta didik tidak berpengaruh terhadap kecakapan sosial peserta didik.

6. Interaksi antara model pembelajaran dan sikap ilmiah peserta didik berpengaruh terhadap kecakapan sosial peserta didik.

Pembelajaran dengan model pembelajaran kooperatif tipe STAD dapat dijadikan salah satu model pembelajaran untuk meningkatkan hasil belajar kognitif dan membangun kecakapan sosial peserta didik. Sikap ilmiah perlu dilatih sejak dini agar dapat memudahkan peserta didik untuk memahami pembelajaran. Pengembangan penelitian serupa dengan pokok bahasan, sampel dan metode yang berbeda perlu dilakukan sehingga dapat meningkatkan kualitas pendidikan.

\section{DAFTAR PUSTAKA}

Anderson, L. W. \& Krathwohl, D. R. (2001). A Taxonomy for Learning, Teaching, and Assessing a Revision of Bloom's Taxonomy of Educational Objectives. New York: Longman, Inc.

Arends, R. I. (2008). Learning to Teach (Belajar untuk Mengajar) Edisi Ketujuh, Helly, P. S. \& Sri, M. S. (Penerjemah). Yogyakarta: Pustaka Belajar.

Arifin, E. Z. (2008). Dasar-Dasar Penulisan Karya Ilmiah Lengkap dengan Kaidah Bahasa Indonesia yang Benar untuk Perguruan Tinggi. Jakarta: Grasindo,

Arizona, K. dan Harjono, A. (2016). Korelasi Kecakapan Sosial, Sikap Ilmiah dan Hasil Belajar Kognitif Fisika Siswa SMP, KONSTAN Vol. 2 No. 2 Hal $14-21$.

Arizona, K., Harjono,A., dan Jufri, AW. (2013). Pengaruh Implementasi Media Tiga Dimensi Kemagnetan Berbasis Inkuiri (MTDKBI) Melalui Strategi 
Kooperatif Terhadap Kecakapan Sosial. ERUDIO (Journal of

Educational Innovation) Vol. 1 No. 2 Hal. $66-70$.

BSNP. (2006). Model Penilaian Kelas Kurikulum Berbasis Kompetensi SMP/MTs. Jakarta: BSNP dan Depdiknas, 2006.

Eggen, P., dan Kauchak, D. (2012). Strategi dan Model Pembelajaran: Mengajarkan Konten dan Keterampilan Berpikir. Satrio Wahono (Penerjemah). Indeks: Jakarta,

Hassard, J. \& Dias, M. (2009). The Art of Teaching Science. London: Oxford University Press.

Ibrahim, M., Rachmadiati, F., Nur, M. \& Ismono. (2000) Pembelajaran Kooperatif. Pusat Sains dan Matematika Sekolah. Program Pascasarjana UNESA. Surabaya: University Press.

Kardi, S \& Nur, M. (2000). Pengantar pada Pengajaran dan Pengelolaan Kelas.

Pusat Sains dan Matematika Sekolah. Program Pascasarjana UNESA. Surabaya: University Press.

Nur, M., dan Wikandari, P.R. (2000). Pengajaran Berpusat kepada Peserta didik dan Pendekatan Konstruktivis dalam Pengajaran. Pusat Studi Matematika dan IPA Sekolah UNESA. Surabaya: University Press.

Puskur. (2007a). Naskah Akdemik Kajian Kebijakan Kurikulum Mata Pelajaran IPA. Jakarta: Pusat Kurikulum, Balitbang Depdiknas.

Puskur. (2007b). Pengembangan Model Pendidikan Kecakapan Hidup. Jakarta: Pusat Kurikulum, Balitbang Depdiknas.

Rusman. (2011). Model-model Pembelajaran Mengembangkan Profesionalisme Guru, Jakarta: Rajagrafindo Persada.

Slavin, R. E. (2011). Psikologi Pendidikan Teori dan Praktik Jilid II Edisi Kesembilan. Penerjemah Marianto Samosir. Jakarta: Indeks. 